\title{
О выявлении цеолитов в Абзелиловском районе Республики Башкортостан
}

\author{
Э.А. Фаткуллин, Р.Д. Шафиков
}

ЗАО «ДИОР», 450065, Уфа, ул. Коммунаров, 53. E-mail: info@ dior-ufa.ru (Статья поступила в редакиию 2 марта 2017 г.)

Рассмотрены перспективы выявления цеолитов в Абзелиловском районе РБ. Представлены вещественный состав и технологическая характеристика ломонтитсодержащих пород Балапанского проявления. Приведены результаты испытаний ломонтита в областях промышленности. Результаты исследований позволяют сделать вывод об эффективности и целесообразности их использования в различных направлениях. Проведена геолого-экономическая оценка эффективности возможного освоения Балапанского проявления.

Ключевые слова: ломонтит, улутауская свита, иеолиты, Балапанское проявление, Башкирия, технологические исследования.

DOI: 10.17072/psu.geol.16.2.156

\section{Введение}

Перспективы выявления месторождений и проявлений цеолитов на территории Абзелиловского района РБ связаны в основном с туфогенно-осадочными толщами улутауской свиты среднего девона, которые по данным Ю.Л. Куваевского прослеживаются с юго-западной границы района на северо-восток в виде узкой полосы субмеридионального направления протяженностью более 50 км. Сведения о выявленных перспективных участках с развитием цеолитовой минерализации на территории района ранее отсутствовали. Однако разработанная геолого-прогнозная модель позволила получить представление о генезисе местных вулканогенноосадочных толщ и связанной с ней цеолитизации. Совокупность проанализированных поисковых критериев (стратиграфических, литологических, тектонических, структурных, магматических и минералого-геохимических) позволила локализовать и оконтурить площадь развития цеолитизации в районе деревни Старобалапаново.

Актуальность постановки работ была обоснована необходимостью создания собственной минерально-сырьевой базы цеолитового сырья для улучшения экологической обстановки в регионе путем применения его в технологических процессах по очистке сточных вод горнорудных предприятий Южного Урала от ионов тяжелых металлов (Хамитов и др. 2012).

Известно, что основные промышленные разновидности природных цеолитов извлекают одновременно все присутствующие в растворе тяжелые металлы с разной степенью эффективности (Аблямитов и др. 2009). Ломонтит до последнего времени являлся менее изученной и обладающей более низкой практической ценностью разновидностью цеолитов. Исходя из этого, геологоразведочные работы проектировались с включением необходимого комплекса технологических исследований для изучения качественных характеристик ломонтитсодержащих пород (Михайлов и др. 1989; Ciambelli et al., 1988; Choi, Hur Nam-Ho, 1995; De Man, van Santen, 1992; Lo Howar, Hung Yung-Tse, 1991; Maegawa, Matsukawa, 1997).

Залежь полезного ископаемого на Балапанской площади отличается изометричной формой и представляет в плане практически равнобедренный треугольник

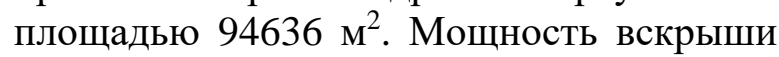
варьирует от 2.7 до 9.0 м, в среднем - 
5.9 м. Средняя мощность полезной толщи составила 34.4 м. Прогнозные ресурсы по категории $\mathrm{P}_{1}$ на Балапанском проявлении оценены в количестве 8.5 млн т ломонтитсодержащих пород. Средневзвешенное содержание ломонтита по Балапанскому проявлению - 29\%, средневзвешенный минеральный состав по продуктивным скважинам и в целом по проявлению приведен в табл. 1.

Таблица 1. Средневзвешенный минеральный состав Балапанского проявления

\begin{tabular}{|c|c|c|c|c|c|c|c|c|c|}
\hline \multirow{2}{*}{ № скважины } & \multicolumn{10}{|c|}{ Фазовый состав, мас. \% } \\
\cline { 2 - 11 } & Лом & Пл & Хл & Кв & Пум & МГА & Сл & Ка & КПШ \\
\hline С-16 & 25.8 & 31.2 & 14.2 & 9.9 & 3.0 & 9.7 & 0.5 & 0.0 & 3.3 \\
\hline С-17 & 37.2 & 15.0 & 0.0 & 9.6 & 16.0 & 0.0 & 0.6 & 0.6 & 0.0 \\
\hline С-19 & 31.0 & 17.5 & 0.0 & 14.0 & 8.3 & 0.0 & 1.3 & 2.3 & 0.0 \\
\hline $\begin{array}{c}\text { Средневзвешенное } \\
\text { по проявлению }\end{array}$ & 29.0 & 25.7 & $\sim 9.0$ & 10.5 & 6.5 & 6.1 & $\sim 0.8$ & $\sim 0.5$ & $\sim 2.1$ \\
\hline
\end{tabular}

Примечание: Лом - ломонтит, Пл - плагиоклаз, Хл - хлорит, Кв - кварц, Пум - пумпеллиит, Мга - минерал из группы амфиболов, Сл - слюда, Ка - кальцит, КПШ - калиевый полевой шпат. АТСИЦ ФГУП «ЦНИИгеолнеруд», исполнители Ф.А. Рахимова, В.В. Власов.

\section{Вещественный состав и технологическая характеристика ломонтитсодержащих пород}

Технологические свойства пород были определены при лабораторных испытаниях. Они заключались в моделировании отдельных элементов первичной переработки ломонтитсодержащих пород и выяснении их качества, а также возможных способов использования в различных отраслях промышленности и сельского хозяйства. Испытания были проведены на трех лабораторно-технологических пробах, составленных из рядовых керновых проб.

Минеральный состав. По результатам петрографических исследований и минералогического анализа методом рентгенографического количественного фазового анализа (РКФА) вулканогенно-осадочные породы улутауской свиты среднего девона на поисковой площади определены как интенсивно выветрелые туфопесчаники, структура которых преимущественно псаммитовая с псефитовыми разностями. Основными породообразующими минералами помимо ломонтита являются плагиоклаз, хлорит, кварц. Второстепенные минералы: пумпеллиит, кальцит, калие- вый полевой шпат, глинистые минералы и минерал из группы амфиболов. Из акцессорных минералов в ломонтитсодержаших породах отмечены минералы из группы моноклинных пироксенов, слюда. Полноценные данные о фазовом составе ломонтитсодержащих пород приведены в табл. 2. Для заверки результатов базового метода РКФА минеральный состав ломонтитсодержащих пород был изучен термогравиметрическим методом анализа (ТГ-ДТГ).

Следует отметить, что исследования методом РКФА хорошо согласуются с данными термогравиметрического метода, а также близки по значению к расчетным средневзвешенным содержаниям ломонтита по скважинам, рядовые пробы которых формируют технологические, что говорит о представительности формирования проб и хорошей достоверности определения минерального состава ломонтитсодержащих пород рентгенографическим анализом. В табл. 3 показаны сравнительные данные содержания ломонтита, определенные двумя независимыми методами: РКФА и ТГ-ДТГ, а также рассчитанные средневзвешенные содержания ломонтита по скважинам, рядовые пробы которых формируют технологические. 
Таблица 2. Фазовый состав ломонтитсодержащих пород

\begin{tabular}{|c|l|l|l|c|c|c|c|c|c|c|}
\hline \multirow{2}{*}{$\begin{array}{c}\text { № про- } \\
\text { бы }\end{array}$} & Лом & Пл & Хл & Кв & Пум & МГА & Ка & КПШ & МГМП & Сл \\
\hline Б-І & 23 & 33 & 14 & 11 & 9 & 7 & $*$ & 3 & $<1$ & следы \\
\hline Б-ІІ & 24 & 32 & 14 & 10 & 5 & 10 & 1 & 3 & $<1$ & 1 \\
\hline Б-Х & 22 & 34 & 16 & 7 & 5 & 9 & 1 & 6 & $*$ & $*$ \\
\hline
\end{tabular}

Примечание: АТСИЦ ФГУП «ЦНИИгеолнеруд», исполнители: Ф. А. Рахимова, В. В. Власов (обозначения см. в примечании к табл. 1).

Таблица 3. Сравнительные данные содержания ломонтита в породах

\begin{tabular}{|c|c|c|c|}
\hline \multirow{2}{*}{$\begin{array}{c}\text { № } \\
\text { пробы }\end{array}$} & \multicolumn{3}{|c|}{ Содержание ломонтита, мас. \% } \\
\cline { 2 - 4 } & РКФА & ТГ-ДТГ & $\begin{array}{c}\text { Средневзвешенные } \\
\text { содержания }\end{array}$ \\
\hline Б-I & 23 & 25 & 25 \\
\hline Б-ІІ & 24 & 30 & 25 \\
\hline Б-X & 22 & 21 & 30 \\
\hline
\end{tabular}

Примечание: АТСИЦ ФГУП «ЦНИИгеолнеруд», исполнители Ф. А. Рахимова, В. В. Власов, А. М. Губайдуллина, А. Н. Халитова, Е. В. Васильева.

Химический состав. Основными характеристиками состава цеолитсодержащих пород являются содержания $\mathrm{SiO}_{2}$ и $\mathrm{Al}_{2} \mathrm{O}_{3}$, при этом большое значение имеет и суммарный состав одно- и двухвалентных катионов $\left(\mathrm{Ca}^{2+}, \mathrm{Mg}^{2+}, \mathrm{Na}^{+}, \mathrm{K}^{+}\right)$, входящих в состав цеолитсодержащих пород, который характеризует ионообменные свойства.

Содержания основных компонентов в ломонтитсодержащих породах $\mathrm{SiO}_{2}$ и $\mathrm{Al}_{2} \mathrm{O}_{3}$ находятся на уровне 57 и $17 \%$ соответственно (табл. 4). Главным преобладающим катионом является кальций. В то же время ломонтитсодержащие породы характеризуются повышенным содержанием $\mathrm{Na}_{2} \mathrm{O}, \mathrm{MgO}$ и $\mathrm{K}_{2} \mathrm{O}$. Из примесей в наибольшем количестве в породе содержится оксид железа. В наименьшем количестве, не превышающем $0,5 \%$, присутствуют $\mathrm{TiO}_{2}, \mathrm{P}_{2} \mathrm{O}_{5}, \mathrm{SO}_{3}$ и $\mathrm{MnO}$.

В результате исследований выявлено, что отношение кремнезема к оксиду алюминия около 3, что позволяет охарактеризовать состав каркаса кристаллической решетки ломонтита как промежуточный между высококремнистыми $(>3,5)$ и низ- кокремнистыми цеолитами с соотношением $\mathrm{Si} / \mathrm{Al}$ как $1: 2,5$. В то же время качественные характеристики термокислотостойкости изучаемых ломонтитов, обусловленные в немалой степени внутрикристаллическим объёмом микрополостей, занятых молекулами воды, а также отношением $\mathrm{Si} / \mathrm{Al}$ и составом катионов, позволяют говорить о их физикохимических и технологических свойствах как более характерных для низкокремнистых цеолитов (Михайлов, Дистанов. 1999).

По валовому содержанию токсичных элементов сырье должно соответствовать ГН 2.1.7.2511-09; СанПиН 2.1.7.1287-03, согласно которым ПДК примесей токсичных элементов в сырье должна составлять (не более): мышьяк - 2.0, кадмий -2.0 , свинец - 32, ртуть - 2.1 мг/кг. Ломонтитсодержащие породы Балапанского проявления по содержанию вредных примесей соответствуют требованиям нормативных документов, что дает возможность использовать их в сельском хозяйстве (табл. $5)$. 
Таблица 4. Химический состав ломонтитсодержащих пород

\begin{tabular}{|c|c|c|c|c|c|c|c|c|c|c|c|c|}
\hline \multirow{2}{*}{$\begin{array}{c}\text { № } \\
\text { пробы }\end{array}$} & \multicolumn{10}{c|}{ Содержание, \% на абс. сухую навеску } \\
\cline { 2 - 13 } & $\mathbf{S i O}_{2}$ & $\mathbf{T i O}_{2}$ & $\mathbf{A l}_{2} \mathbf{O}_{3}$ & $\mathbf{F e}_{2} \mathbf{O}_{3}$ & $\mathbf{M n O}$ & $\mathbf{C a O}$ & $\mathbf{M g O}$ & $\mathbf{N a}_{2} \mathbf{O}$ & $\mathbf{K}_{2} \mathbf{O}_{2}$ & $\mathbf{P}_{2} \mathbf{O}_{5}$ & $\mathbf{S O}_{3}$ & IIII \\
\hline Б-I & 57.50 & 0.41 & 17.09 & 6.27 & 0.12 & 5.86 & 2.86 & 2.94 & 1.78 & 0.12 & 0.12 & 4.99 \\
\hline Б-II & 57.45 & 0.44 & 17.03 & 6.14 & 0.13 & 5.74 & 2.87 & 3.08 & 1.80 & 0.15 & 0.15 & 5.00 \\
\hline Б-X & 56.85 & 0.44 & 17.89 & 6.24 & 0.12 & 6.14 & 2.67 & 3.11 & 1.59 & 0.07 & 0.11 & 5.07 \\
\hline
\end{tabular}

Примечание: АТСИЦ ФГУП «ЦНИИгеолнеруд», исполнители Н. В. Князева, Р. Р. Гильмутдинов, Е. Н. Шунина.

Таблица 5. Содержание вредных примесей в ломонтитсодержащих породах

\begin{tabular}{|c|c|c|c|c|c|c|c|c|}
\hline \multirow{2}{*}{$\begin{array}{c}\text { № } \\
\text { пробы }\end{array}$} & \multicolumn{6}{|c|}{ Содержание, мг/кг на абс. сухую навеску } \\
\cline { 2 - 8 } & $\mathbf{A s}$ & $\mathbf{H g}$ & $\mathbf{P b}$ & $\mathbf{C d}$ & $\mathbf{S b}$ & $\mathbf{C r}$ & $\mathbf{C u}$ & $\mathbf{F}$ \\
\hline Б-I & 1.6 & 0.02 & 3.5 & 0.09 & 0.09 & 14 & 14 & 0.039 \\
\hline Б-ІІ & 0.97 & 0.21 & 2.7 & 0.08 & 0.06 & 5.9 & 12 & 0.039 \\
\hline Б-Х & 1.88 & $<0.01$ & 5.5 & 0.15 & 0.17 & 2.6 & 15 & 0.04 \\
\hline
\end{tabular}

Примечание: АТСИЦ ФГУП «ЦНИИгеолнеруд», исполнители О. Г. Иглина, В. А. Пудова, Р. Р. Гильмутдинов.

Катионообменные свойства. По своему катионному составу ломонтитсодержащие породы представляют $\mathrm{Ca}$ форму (содержание катионов $\mathrm{Ca}^{++}$ варьирует от 12.48 до 16.97 мг-экв., $\mathrm{Mg}^{++}$ - от 0.82 до 1.64 мг-экв., содержание катионов $\mathrm{K}^{+}$и $\mathrm{Na}^{+}$менее 1 мг-экв.). Таким образом, содержание катионов в породах можно расположить в следующий ряд: $\mathrm{Ca}^{++}>\mathrm{Mg}^{++}>\mathrm{Na}^{+}>\mathrm{K}^{+}$.
Преимущественно кальциевый состав катионов позволяет рекомендовать ломонтитсодержащие породы для применения в качестве богатой Са кормовой добавки и улучшения качества лесостепных почв Башкирского Зауралья, а также в качестве компонента цементной шихты. Сумма катионного обмена у ломонтитсодержащих пород находится в диапазоне от 14.66 до 19.31 мг-экв. (табл. 6).

Таблица 6. Катионообменная способность ломонтитсодержащих пород

\begin{tabular}{|c|c|c|c|c|c|}
\hline \multirow{2}{*}{$\begin{array}{c}\text { № } \\
\text { пробы }\end{array}$} & \multicolumn{5}{|c|}{ Содержание, мг-экв. на воздушносухую } \\
\cline { 2 - 6 } & $\mathbf{C a}^{++}$ & $\mathbf{M g}^{++}$ & $\mathbf{N a}^{+}$ & $\mathbf{K}^{+}$ & Сумма \\
\hline Б-I & 12.48 & 1.64 & 0.44 & 0.10 & 14.66 \\
\hline Б-II & 16.97 & 1.64 & 0.44 & 0.26 & 19.31 \\
\hline Б-Х & 13.97 & 0.82 & $<0.01$ & $<0.01$ & 14.79 \\
\hline
\end{tabular}

Примечание: АТСИЦ ФГУП «ЦНИИгеолнеруд», исполнитель Ю. С. Багаутдинова.

Радиационные характеристики. По радиационным характеристикам значения Аэфф+погреш. у ломонтитсодержащих пород Балапанской площади находятся в диапазоне от $27 \pm 3$ до $50 \pm 5$ Бк/кг, что ниже параметра (Аэфф+погреш. $<370$ Бк/кг), регламентированного «Нормами радиационной безопасности НРБ-99/2009».
Гамма-активность ломонтитсодержащих пород соответствует материалам I класса, из этого следует, что цеолиты Балапанского проявления радиационно безопасны и могут быть использованы во всех производствах без ограничения. Результаты определения естественной радиоактивности приведены в табл. 7. 
Таблица 7. Радиащионные характеристики пород Балапанского проявления

\begin{tabular}{|c|c|c|c|c|c|}
\hline \multirow[b]{2}{*}{ № пробы } & \multicolumn{5}{|c|}{ Удельная активность радионуклидов, Бк/кГ } \\
\hline & $\begin{array}{c}\text { Аэфф士 } \\
\text { погреш. }\end{array}$ & $\begin{array}{c}{ }^{232} \mathrm{Th} \pm \\
\text { абс. погр. }\end{array}$ & $\begin{array}{c}{ }^{226} \mathrm{Ra} \pm \\
\text { aбс. погр. }\end{array}$ & $\begin{array}{c}{ }^{40} \mathrm{~K} \pm \\
\text { абс. погр. }\end{array}$ & $\begin{array}{c}{ }^{137} \mathrm{Cs} \pm \\
\text { абс. погр }\end{array}$ \\
\hline Б-I & $27 \pm 3$ & $1.8 \pm 0.8$ & $10.3 \pm 2.0$ & $274.0 \pm 33.0$ & $<2$ \\
\hline Б-II & $50 \pm 5$ & $3.7 \pm 1.0$ & $10.0 \pm 2.0$ & $394.0 \pm 45.0$ & $<2$ \\
\hline Б-X & $41 \pm 4$ & $2.6 \pm 1.0$ & $9.2 \pm 1.2$ & $313.0 \pm 45.0$ & $<2$ \\
\hline $\begin{array}{c}\text { Средние зна- } \\
\text { чения по про- } \\
\text { явлению }\end{array}$ & $39 \pm 4$ & $2.7 \pm 0.9$ & $9.8 \pm 1.7$ & $327.0 \pm 41.0$ & $<2$ \\
\hline
\end{tabular}

Примечание: АТСИЦ ФГУП «ЦНИИгеолнеруд», исполнители Г. М. Семенова, Е. В. Сорокина, Н. Н. Пихтина.

Термоустойчивость. Термическую устойчивость необходимо учитывать при проектировании способов активации или модифицирования перерабатываемого сырья. Кроме того, исследования позволяют получить сведения о дегидратации и термостабильности цеолитсодержащих пород. В табл. 8 приведены термографические и термогравиметрические характеристики изученных ломонтитсодержащих пород. Отмечено, что цеолитная вода из породы выделяется в три этапа: в интервале температур $30-140{ }^{\circ} \mathrm{C}$ (удаляется от 0.54 до $1.17 \%$ общей массы воды, максимум эффекта при 72-79 ${ }^{\circ} \mathrm{C}$ ), при 140-285 ${ }^{\circ} \mathrm{C}$ (удаляется от 0.81 до $1.29 \%$ общей массы воды, максимум эффекта при 203$208{ }^{\circ} \mathrm{C}$ ) и при $285-445{ }^{\circ} \mathrm{C}$ (удаляется от 1.02 до $1.30 \%$ общей массы воды, максимум эффекта при $375-388{ }^{\circ} \mathrm{C}$ ). Потери цеолитной воды у всех изученных ломонтитсодержащих пород практически одного порядка. В области температур 445-645 ${ }^{\circ} \mathrm{C}$ структурная вода выделяется в количестве от 1.31 до 1.57 мас. \%, максимум эффекта при 540-601 ${ }^{\circ} \mathrm{C}$. В интервале температур $645-999^{\circ} \mathrm{C}$ наблюдается потеря массы, соответствующая диссоциации кальцита и примесей пренита. Замечено, что содержание ломонтита в породе не влияет на общее количество удаленной воды. В среднем общее изменение массы в интервале температур $330-1000{ }^{\circ} \mathrm{C}$ составляет от 4.16 до 5.96 мас. \% (табл. 8).

Физико-механические параметры. Проведение различных технологических процессов с высокими гидродинамиче- скими нагрузками требует детального анализа исследований ломонтитсодержащих пород на устойчивость к различным механическим нагрузкам. С этой целью для ломонтитсодержащих пород были определены физико-механические показатели: плотность, объемная масса, насыпная масса, предел прочности при сжатии, виброизнос, пористость, водостойкость, влажность (табл. 9).

В целом по основным физикомеханическим параметрам ломонтитсодержащие породы Балапанского проявления соответствуют требованиям промышленности. Так, показатели механической прочности полностью соответствуют лимитируемым значениям данного параметра в сорбционных процессах. Показатели водостойкости и виброизноса близки к аналогичным параметрам известных разрабатываемых месторождений восточной части России: Холинское, Шивыртуйское, Хонгуруу, а также согласуются с нормами, рекомендованными в сельском хозяйстве и очистке загрязненных вод. В то же время ломонтитсодержащие породы обладают низкими значениями удельной поверхности, пористости и объема пор.

Таким образом, в результате проведенного анализа следует заключить, что ломонтитсодержащие породы Балапанской площади в целом, по основным физико-механическим параметрам, соответствуют требованиям промышленности и могут использоваться в технологических процессах. 
Таблица 8. Результаты исследования лабораторно-технологических проб цчеолитсодержащих пород термогравиметрическим (ТГ-ДТГ) методом

\begin{tabular}{|c|c|c|c|c|c|c|c|c|c|}
\hline \multirow{2}{*}{$\begin{array}{c}\text { № } \\
\text { пробы }\end{array}$} & \multicolumn{6}{|c|}{$\begin{array}{c}\text { Интервал температур (максимум эффекта, }{ }^{\circ} \mathrm{C} \text { ) } \\
\text { потеря массы, мас. \% }\end{array}$} & \multirow{2}{*}{$\begin{array}{c}\text { Общее измене- } \\
\text { ние массы в } \\
\text { интервале } 330 \text { - } \\
\mathbf{1 0 0 0}^{\circ} \mathrm{C} \text {, мас. \% }\end{array}$} & \multirow{2}{*}{$\begin{array}{c}\text { Содер- } \\
\text { жание } \\
\text { кальци- } \\
\text { та, мас. } \\
\text { \% }\end{array}$} & \multirow{2}{*}{$\begin{array}{c}\text { Содер- } \\
\text { жание } \\
\text { ломон- } \\
\text { тита, } \\
\text { мас. \% }\end{array}$} \\
\hline & $\begin{array}{c}30-140 \\
{ }^{\circ} \mathrm{C}\end{array}$ & $\begin{array}{c}140- \\
285^{\circ} \mathrm{C}\end{array}$ & $\begin{array}{l}285- \\
445^{\circ} \mathrm{C}\end{array}$ & $\begin{array}{l}445- \\
645^{\circ} \mathrm{C}\end{array}$ & \multicolumn{2}{|c|}{$645-999^{\circ} \mathrm{C}$} & & & \\
\hline Б-I & $\begin{array}{l}0.85 \\
(72)\end{array}$ & $\begin{array}{l}0.94 \\
(207)\end{array}$ & $\begin{array}{c}1.10 \\
(378)\end{array}$ & $\begin{array}{l}1.57 \\
(540)\end{array}$ & $\begin{array}{c}0.41 \\
645-755 \\
(674)\end{array}$ & $\begin{array}{l}0.35 \\
755- \\
\underline{999} \\
\end{array}$ & 5.22 & $1 \pm 0.5$ & 25 \\
\hline Б-II & $\begin{array}{l}1.17 \\
(79)\end{array}$ & $\begin{array}{l}1.29 \\
(208)\end{array}$ & $\begin{array}{l}1.30 \\
(388)\end{array}$ & $\begin{array}{l}1.47 \\
(601)\end{array}$ & $\begin{array}{c}0.65 \\
645-756 \\
(696)\end{array}$ & $\begin{array}{l}0.09 \\
756- \\
999 \\
\end{array}$ & 5.96 & $1 \pm 0.5$ & 30 \\
\hline Б-X & $\begin{array}{l}0.54 \\
(78) \\
\end{array}$ & $\begin{array}{c}0.81 \\
(203) \\
\end{array}$ & $\begin{array}{c}1.02 \\
(375) \\
\end{array}$ & $\begin{array}{c}1.31 \\
(544) \\
\end{array}$ & $0.45(708)$ & $\begin{array}{c}0.03 \\
(-) \\
\end{array}$ & 4.16 & 1 & 21 \\
\hline
\end{tabular}

Примечание: АТСИЦ ФГУП «ЦНИИгеолнеруд», А.М. Губайдуллина, А.Н. Халитова, Е.В. Васильева.

Таблица 9. Физико-механические параметры ломонтитсодержащих пород

\begin{tabular}{|c|c|c|c|c|c|c|}
\hline \multirow[b]{2}{*}{ Проба } & \multirow[b]{2}{*}{$\begin{array}{c}\text { Фракция, } \\
\text { мм }\end{array}$} & \multirow[b]{2}{*}{$\begin{array}{c}\text { Влажность, } \\
\%\end{array}$} & \multirow{2}{*}{ 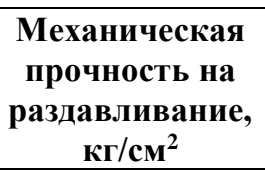 } & \multirow{2}{*}{$\begin{array}{c}\text { Виброизнос, } \\
\%\end{array}$} & \multicolumn{2}{|c|}{ Водостойкость, \% } \\
\hline & & & & & $\begin{array}{c}\text { с кипяче- } \\
\text { нием }\end{array}$ & $\begin{array}{c}\text { без кипя- } \\
\text { чения }\end{array}$ \\
\hline 5-I & $1-3$ & 1.10 & 150 & 1.30 & 98.1 & 98.1 \\
\hline Б-II & $1-3$ & 0.98 & 117 & 1.54 & 96.2 & 96.7 \\
\hline Б-X & $2-4$ & 1.62 & $(144) * 176$ & 1.60 & 99.6 & 99.7 \\
\hline
\end{tabular}

Примечание: показатель механической прочности определен на не термообработанных образцах. АТСИЦ ФГУП «ЦНИИгеолнеруд», Т.Н. Чуприна, Е.Н. Скворцова, Т.В. Ильина, Е.В. Ризаева

Таблица 10. Адсорбиионно-структурные показатели ломонтитсодержащих пород

\begin{tabular}{|c|c|c|c|c|c|c|c|c|}
\hline \multirow[b]{2}{*}{ Проба } & \multirow[b]{2}{*}{$\begin{array}{c}\text { Фракция, } \\
\text { мм }\end{array}$} & \multicolumn{3}{|c|}{ 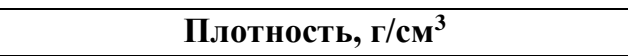 } & \multirow{2}{*}{ 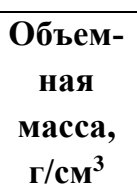 } & \multirow[b]{2}{*}{$\begin{array}{c}\text { Пори- } \\
\text { сто- } \\
\text { сть, \% }\end{array}$} & \multirow[b]{2}{*}{$\begin{array}{c}\text { Объем } \\
\text { пор, } \text { см }^{3}\end{array}$} & \multirow[b]{2}{*}{$\begin{array}{c}\text { Уд.пов. } \\
\text { по толуо- } \\
\text { лу, м²/Г }\end{array}$} \\
\hline & & $\begin{array}{c}\text { истин- } \\
\text { ная }\end{array}$ & кажущаяся & $\begin{array}{c}\text { насып. } \\
\text { нагруз. } 80 \text { н }\end{array}$ & & & & \\
\hline Б-I & $1-3$ & $\begin{array}{c}2.6652 \pm \\
0.0006\end{array}$ & $\begin{array}{c}2.2494 \pm \\
0.0019\end{array}$ & $1.4203 \pm 0.0035$ & 1.2785 & 15 & 0.0693 & 12 \\
\hline Б-II & $1-3$ & $\begin{array}{c}2.6193 \pm \\
0.0009\end{array}$ & $\begin{array}{c}2.1464 \pm \\
0.0018\end{array}$ & $1.4137 \pm 0.0037$ & 1.2584 & 18 & 0.0841 & 18 \\
\hline Б-X & $2-4$ & $\begin{array}{c}2.6206 \pm \\
0.0003\end{array}$ & $\begin{array}{c}2.3104 \pm \\
0.0040\end{array}$ & $1.3971 \pm 0.0047$ & 1.2799 & 11 & 0.0512 & 18 \\
\hline
\end{tabular}

Примечание: АТСИЦ ФГУП «ЦНИИгеолнеруд», О. А. Михайлова, Е. Н. Скворцова.

Лабораторно-технологические испытания по определению возможности использования минерального сырья в промышленности

Возможность использования пород для очистки сточных карьерных вод от ионов тяжелых металлов. На эффектив- ность извлечения тяжелых металлов природными цеолитами влияют многие факторы: особенности состава и структуры цеолита, физико-химические и химические характеристики раствора, динамика и условия проведения процесса очистки воды. По данным Т.П. Конюховой и Д.А. Кикило, в зависимости от рН в рас- 
творах могут находиться разные формы ионов, которые характеризуются разной способностью к обмену на природных цеолитах.

Таблица 11. Оиенка качества физикомеханических свойств иеолитов по направлениям использования (Т.П. Конюхова, У.Г. Дистанов)

\begin{tabular}{|l|c|c|}
\hline \multicolumn{1}{|c|}{ Показатель } & $\begin{array}{c}\text { Сорбци- } \\
\text { онные } \\
\text { процессы }\end{array}$ & $\begin{array}{c}\text { Сель- } \\
\text { ское } \\
\text { хозяй- } \\
\text { ство }\end{array}$ \\
\hline $\begin{array}{l}\text { Механическая проч- } \\
\text { ность на раздавлива- } \\
\text { ние, кг/см }{ }^{3}, \text { не менее }\end{array}$ & 90 & $\begin{array}{l}\text { не лими- } \\
\text { тируется }\end{array}$ \\
\hline $\begin{array}{l}\text { Водостойкость, \%, не } \\
\text { менее }\end{array}$ & 96 & 96 \\
\hline $\begin{array}{l}\text { Виброизнос, \%, не } \\
\text { более }\end{array}$ & 3 & 3 \\
\hline $\begin{array}{l}\text { Насыпная плотность, } \\
\text { г/см }{ }^{3}, \text { не более }\end{array}$ & $0,8500-$ & $0,6200-$ \\
\hline $\begin{array}{l}\text { Удельная поверхность } \\
\text { по толуолу, м²/г }\end{array}$ & $50-105$ & $45-100$ \\
\hline Пористость, \% & $45-60$ & $40-60$ \\
\hline
\end{tabular}

Для объективной оценки пригодности ломонтитсодержащих пород Балапанского проявления в качестве фильтрующего материала очистных сооружений горнообогатительных комбинатов Башкирского Зауралья были проведены модельные эксперименты. Для этого в лабораторных условиях был воспроизведен точный химический состав технологически загрязненных карьерных вод Сибайского ГОКа.

Проведенные испытания по очистке загрязненных вод от ионов тяжелых металлов в статических условиях показали, что рассмотренные ломонтитсодержащие породы очищают воду от ионов меди, цинка до ПДК. Остальные ионы (марганец, никель, железо, кобальт, свинец) ломонтитсодержащие породы очищают при определенных соотношениях Т:Ж (твердой и жидкой фаз), т.е. фильтрующего материала (ломонтита) и загрязненной воды. Так, к примеру, лабораторно-технологическая проба Б-II при соотношении Т:Ж 25:100 очистила воду до ПДК от ионов меди, никеля, кобальта, цинка, железа, свинца.

Испытания, проведенные в динамических условиях, установили, что ломонтитсодержащие породы очистили до ПДК 18.5 л воды от ионов меди при степени очистки 85.5-95.0 \% и динамической емкости $0.3835 \%$ и 18 л воды от ионов цинка при степени очистки 63.0-88.5 \% и динамической емкости $0.11 \%$.

Возможность использования пород для очистки дизельных и растительных масел. Основными технологическими показателями для оценки пригодности использования различных пород в процессах очистки растительных масел и нефтепродуктов являются маслоемкость, фильтрующая и отбеливающая способность.

Перед испытаниями пробы измельчались до $<1,0$ мм. Масса очищаемых масел составляла 100 г, а количество ломонтитсодержащей породы $5 \%$ от их массы.

Для испытаний с Казанского жирового комбината взято нерафинированное масло. Начальная цветность масла 2 ед. ЦНТ. В качестве нефтепродукта исследовалась смесь дизельного масла М-10Г2К, изготовленного ОАО «Пушкинским заводом» (г.Пушкин),с начальной цветностью 4.5 ед. ЦНТ и отработанного машинного масла в соотношении 100:1.

Результаты испытаний показали, что очистка нерафинированного подсолнечного масла ломонтитсодержащими породами приводит к его осветлению с 2.0 ед. до 1.5. Соответственно отбеливающая способность масла составляет $25 \%$, а маслоемкость 11,4\% (табл. 12). 
Таблица 12. Основные технологические показатели ломонтитсодержащих пород при очистке нерафинированного подсолнечного и дизельного масла

\begin{tabular}{|c|c|c|c|c|}
\hline \multirow{2}{*}{ Масло } & \multicolumn{2}{|c|}{ Цвет, ед. ЦНТ } & \multirow{2}{*}{$\begin{array}{c}\text { Отбеливающая } \\
\text { способность, } \\
\text { \% }\end{array}$} & $\begin{array}{c}\text { Маслоемкость, } \\
\text { \% }\end{array}$ \\
\cline { 1 - 3 } & исходный & $\begin{array}{c}\text { после } \\
\text { очистки }\end{array}$ & 25 & 11.4 \\
\hline $\begin{array}{c}\text { Нерафинированное } \\
\text { подсолнечное }\end{array}$ & 2.0 & 1.5 & 0 & 12.5 \\
\hline Дизельное & 4.5 & 4.5 & 0 & 25 \\
\hline
\end{tabular}

Примечание: АТСИЦ ФГУП «ЦНИИгеолнеруд», исполнитель Т. Н. Чуприна.

Очистка дизельных масел ломонтитсодержащими породами не приводит к существенному осветлению. Цвет очищенного дизельного масла либо остаётся прежним, либо светлеет незначительно, следовательно, отбеливающая способность вещества также низкая.

Таким образом, изучаемые ломонтитсодержащие породы для очистки нефтепродуктов ввиду низкой эффективности использовать не рекомендуется. Для подтверждения пригодности ломонтитсодержащих пород для очистки от нефтепродуктов необходимо провести дополнительные испытания на других видах нефтепродуктов при соответствующем подборе условий технологического процесса очистки. В то же время ломонтитсодержащие породы можно рекомендовать после дополнительных исследований в качестве средства очистки растительных масел. В частности, целесообразно проведение работ по активации пород механическими способами и подбору соответствующих параметров процесса очистки.

Применение цеолитсодержащих пород в качестве кормодобавок. Одним из перспективных направлений применения цеолитов в животноводстве и птицеводстве является использование их в качестве подкормок скота, птиц и других животных.

В научных работах, выполненных в нашей стране и за рубежом, доказана высокая технико-экономическая и биологическая эффективность применения природных цеолитов в качестве добавок в корма сельскохозяйственных животных и птицы. Это позволяет повысить биологическую ценность кормов за счет их сбалансирования по питательным, минеральным и биологически активным веществам.

Суммарный эффект действия цеолита на организм животных и птиц проявляется в увеличении их продуктивности. Понижается заболеваемость, повышается сохранность поголовья, улучшаются качественные показатели продукции.

Проведен анализ научно-технических и аналитических исследований применения цеолитсодержащих пород в качестве кормодобавок, на основании которых установлено, что исследуемые ломонтитсодержащие породы в целом соответствуют нормам и требованиям и могут использоваться в качестве кормодобавок.

Для более полной и объективной оценки применения ломонтитсодержащих пород в качестве минеральной кормовой добавки необходимо продолжить опытные испытания эффективности действия питательных кормовых добавок при выращивании сельскохозяйственных животных и птицы, а также определить необходимые нормы внесения.

Использования ломонтитсодержащих пород для реабилитации почв. В качестве объектов исследования в экспериментах использованы профильные образцы целинных лесостепных почв - темно-серой лесной и выщелоченного чернозема, являющиеся аналогом почв юга Республики Башкортостан. Почвы отобраны сотрудниками кафедры почвоведения Казанского федерального университета и детально 
охарактеризованы по минералогическому составу. Полученные результаты показали перспективность использования ломонтитсодержащих пород для экологической реабилитации почв.

\section{Геолого-экономическая оценка Бала- панского проявления}

Расчет показателей стоимостной оценки участка Балапанской площади выполнен на 01.01.2015 по методике ВИЭМС (г.Москва). В качестве аналогов в расчете использованы технико-экономические показатели Левашинского и Рубасчайского проявлений цеолитов и цеолитсодержащих пород Нагорного Дагестана, определенные в ЦНИИгеолнеруд в 2009 г.

Полученные технико-экономические значения промышленной значимости и возможного освоения ресурсов нельзя рассматривать как окончательные. Для окончательного заключения необходимо составить технико-экономические обоснования. Проведенная геолого-экономическая оценка прогнозных ресурсов ломонтитсодержащих пород Балапанской площади по укрупненным показателям подтверждает, что освоение проявления признано эффективным. Нормативный показатель рентабельности предприятия составит $12 \%$, а срок окупаемости капитальных вложений - 3.4 года.

\section{Заключение}

Результаты поисковых работ на цеолитсодержащие породы в Башкирском Зауралье указывают на наличие весомых геологических, минералого-технологических и геолого-экономических аргументов, доказывающих реальную целесообразность создания в Республике Башкортостан собственной минеральносырьевой базы цеолитового сырья.

По данным лабораторно-технологических испытаний установлено, что ломонтитовое сырье может быть эффективно использовано в следующих направлениях:
- в доочистке карьерных сточных вод от ионов меди и цинка;

- очистке почвы от нефтепродуктов;

- в качестве отбеливающего материала в очистке пищевых растительных масел;

- в качестве добавки в корма животных и птиц для повышения продуктивности, экономии корма.

Установить окончательную целесообразность и рассчитать эффективность использования ломонтитсодержащих пород в различных направлениях возможно только путем проведения прямых технологических испытаний.

Потенциальными потребителями цеолитового сырья на территории Республики Башкортостан могут стать очистные сооружения сточных вод, горнообогатительные комбинаты региона (Сибайский, Бурибаевский и Учалинский ГОКи), нефтедобывающие, нефтеперерабатывающие предприятия и предприятия химической промышленности, а также сельскохозяйственные предприятия.

Исследования цеолитоносности Абзелиловского района и в целом Башкирского Зауралья могут быть продолжены по многим аспектам. Первоочередным направлением является дальнейшее изучение толщ тефроидов улутауской свиты среднедевонского возраста на выявление геологических факторов, обуславливающих процессы образования цеолитов. Особое внимание необходимо сосредоточить на литологически однородных вулканогенно-осадочных флишоидных образованиях на границах зон комплекса пород, подвергнутых пренит-пумпеллиитовой фации ретроградного метаморфизма.

Логичным и необходимым видится проведение комплекса разведочных работ для уточнения геологической структуры, формы и условий залегания ломонтитсодержащих руд, их качества, в процессе которых будут дополнительно изучены технологические характеристики ломонтитсодержащих пород для отработки параметров промышленного использования. 


\section{Библиографический список}

Аблямитов П.О., Лыгина Т.З., Буров А.И. Цеолитовые руды месторождений России и оптимальное комплексирование методов по оценке их качества // Разведка и охрана недр, 2009. № 10. С. 12-18.

Дистанов У.Г., Конюхова Т.П. Минеральное сырье. Сорбенты природные: справочник. М.: ЗАО «Геоинформмарк», 1999. 42с.

Михайлов А.С., Дистанов У.Г. Минеральное сырье. Цеолиты: справочник. М.: ЗАО «Геоинформмарк», 1999. 29c.

Михайлов А.С., Буров А.И., Власов В.В. и др. Поиски, разведка и оценка месторождений цеолитсодержащих пород / ВИЭМС. М. $1989.54 \mathrm{c}$.

Хамитов Р.А., Корнилов А.М., Жданов Г.Ш. О перспективах использования природных цеолитов Зауралья Башкортостана для решения проблемы промышленной экологии, строительства, ЖКХ и потребностей сельского хозяйства // Перспективы созда- ния новых горнорудных районов в европейской части России и Урала. М., 2012.

Ciambelli P., Corbo P., Liber L., Lopez A. Ammonium recovery from urban sewage by natural zeolites Occurrence, Prop. and Ul. // Natur. Zeolites: 2nd Int. Conf., Budapest, g. 1216. Budapest, 1988. P. 501-509.

Choi J., Hur Nam-Ho. Study on the CEC increase and granulaon of natural zeolite. 3. Effects of alkali treatment on the ammonium and potassium ionadrpon of natural zeolite // Han'guk T'oyang Piiyo. Haklioechi. 1995. Vol. 28, № 1.P. 22 -27.

De Man A.J.M., van Santen R.A. The relaon between zeolite framework structure and vibraonal spectra // Zeolites. 1992. Vol. 12. № 3. P. $269-279$.

Lo Howard H., Hung Yung-Tse. Ulizaon of clays and zeolites for coagulaon treatment of municipal wastewater // Int. J. Environ. Stud. 1991. Vol.37.№ 3. P. 203 -212.

Maegawa Akira, Matsukawa Susumi. Feasibility study of zeolite materials for water purificaon // II Rep. Ind. Res. Cent. Shiga Prefect. 1997. Vol. 10. P. 49 - 56.

\section{Prospects of Zeolites Exploration in Abzelilovskiy District of the Bashkortostan Republic}

\section{E.A. Fatkullin, R.D. Shafikov \\ JSC DIOR, 53 Kommunarov Str, Ufa 450065, Russia. E-mail: info@dior-ufa.ru}

The article considers the exploration prospects of zeolites mineralization in Abzelilovskiy district of the Republic of Bashkortostan. The detailed composition and technological characteristics of laumontite-bearing rocks of the Balapanskoe occurrence are presented. The practical results of testing of the laumontite in industry are shown. The results of study allowed confirming the effectiveness and feasibility of its usage in different industrial processes. A geological-economic assessment of the efficiency of development of the Balapanskoe deposit was conducted.

Key words: laumontite; the Ulutau Suite; zeolite-bearing rocks; Balapanskoye deosit; Abzelilovsky district; technological studies.

\section{References}

Ablyamitov P.O., Lygina T.Z., Burov A.I. 2009. Tseolitovye rudy mestorozhdeniy Rossii i optimalnoye kompleksirovaniye metodov po otsenke ikh kachestva [Zeolite ore deposits in Russia and optimal integration of methods for assessing their quality]. Razvedka i okhrana nedr. 10:12-18. (in Russian)
Distanov U.G., Konyukhova T.P. 1999. Mineralnoye syryo. Sorbenty prirodnye: spravochnik [Mineral raw materials. Natural sorbents: Handbook]. Moskva, ZAO Geoinformmark, p. 42. (in Russian)

Mikhaylov A.S., Distanov U.G. 1999. Mineralnoye syryo. Tseolity: spravochnik [Mineral raw materials. Zeolites: Handbook]. Moskva. ZAO Geo-informmark, p. 29. (in Russian) 
Mikhaylov A.S., Burov A.I., Vlasov V.V. et al. 1989. Poiski, razvedka i otsenka mestorozhdeniy tseolitsoderzhashchikh porod [Prospecting, exploration and evaluation of deposits of zeolite-bearing rocks]. Moskva, VIEMS, p. 54. (in Russain)

Khamitov R.A., Kornilov A.M., Zhdanov G.SH. 2012. O perspektivakh ispolzovaniya prirodnykh tseolitov Zauralya Bashkortostana dlya resheniya problemy promyshlennoy ekologii, stroitelstva, ZHKKH i potrebnostey selskogo khozyaystva [On the prospects of the use of natural zeolites of the Bashkortostan Zauralye for solving the problems of ecology, construction industry, housing and farming] In Perspektivy sozdaniya novykh gornorudnykh rayonov $\mathrm{v}$ yevropeyskoy chasti Rossii i Urala. Moskva.

Ciambelli P., Corbo P., Liber L., Lopez A. 1988. Ammonium recovery from urban sewage by natural zeolites. In Occurrence, Prop., and
Util. of Natur. Zeolites. Proc. of 2nd Int. Conf., Budapest, pp. 501-509.

Choi J., Hur Nam-Ho. 1995. Study on the CEC increase and granulaon of natural zeolite -3Effects of alkali treatment on the ammonium and potassium ion adsorption of natural zeolite. Han'guk T'oyang Piiyo. Haklioechi. 28: $22-27$.

De Man A.J.M., van Santen R.A. 1992. The relation between zeolite framework structure and vibrational spectra. Zeolites. 12(3):269 -279. doi: 10.1016/S0144-2449(05)80295-7

Lo Howard H., Hung Yung-Tse. 1991. Utilization of clays and zeolites for coagulation treatment of municipal wastewater. Int. J. Environ. Stud. 37(3): 203 -212. doi: 10.1080/00207239108710631

Maegawa Akira, Matsukawa Susumi. 1997. Feasibility study of zeolite materials for water purification. Rep. Ind. Res. Cent. Shiga Prefect. 10:49 - 56. 